\title{
UNIVERSITÁRIOS E A INFORMAÇÃO JORNALÍSTICA: UM ESTUDO SOBRE O ACESSO DA JUVENTUDE CURITIBANA À NOTÍCIA
}

\author{
UNIVERSITY STUDENTS AND JOURNALISTIC INFORMATION: A SURVEY \\ ON CURITIBA'S YOUTH ACCESS OF TO NEWS
}

\author{
UNIVERSITARIOS Y LA INFORMACIÓN PERIODÍSTICA: UN ESTUDIO \\ SOBRE EL ACCESO DE LOS JÓVENES CURITIBANOS A LAS NOTICIAS
}

\author{
Elza Aparecida Oliveira Filha \\ Dra., UTFPR \\ elzaap@hotmail.com
}

\section{Resumo}

Mais de $70 \%$ dos universitários curitibanos têm hábito de buscar informações jornalísticas com frequência ( $37 \%$ o fazem todos os dias e outros $37 \%$ algumas vezes por semana); $59 \%$ apontam a televisão como sua principal fonte, mas o facebook segue perto, com $56 \%$ das preferências. O jornal impresso, embora seja menos lido, tem uma folgada margem de confiança dos estudantes: $65 \%$ dizem confiar mais nas informações veiculadas nesta mídia. Estes dados fazem parte dos resultados de uma sondagem junto a 470 universitários dos cursos de Direito e Engenharia Civil de quatro instituições de ensino superior de Curitiba. O trabalho foi desenvolvido por estudantes matriculados na disciplina Pesquisa em Jornalismo, da Universidade Positivo, que buscavam compreender aspectos da recepção de notícias por jovens, entendendo que esta é uma indagação de extrema relevância no atual momento de transformações vivido pela atividade jornalística.

Palavras-chave: mídias jornalísticas, consumo de notícias, universitários

Abstract: Over $70 \%$ of college students from Curitiba seek journalistic information frequently (37\% do so every day and $37 \%$ a few times a week), $59 \%$ declare television as their main source of news consumption, and 56\% prefer facebook. The printed newspaper, though not so frequently read, has a good margin of confidence among students: 65\% say they rely more on information published on this type of media. The data presents the results from a survey conducted with 470 college students from Law and Civil Engineering in four Universities in Curitiba. The study was conducted by students enrolled in the course Journalism Research and it seeks to understand aspects of news reception among young people, since it is an issue of great relevance in the present moment of transformation experienced by journalistic activity.

Keywords: news media, news consumption, university

Resumen: Más del $70 \%$ de los estudiantes universitarios curitibanos tienen costumbre de buscar información periodística con frecuencia (37\% lo hace todos los días y otros $37 \%$ un par de veces a la semana); el 59\% dijo que la televisión es su fuente principal, pero facebook aparece con el $56 \%$ de las preferencias. El periódico impreso, aunque menos de lectura, tiene un buen margen de confianza de los estudiantes: $65 \%$ dicen que confían más en la información publicada por este medio. Estos datos son parte de los resultados de una encuesta de 470 estudianties universitários, de Derecho e Ingeniería Civil, de quatro instituciones de educación superior de Curitiba. El estudio fue realizado por los alumnos

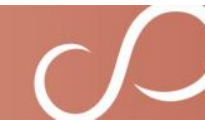


matriculados en el curso de Investigación en Periodismo buscando comprender aspectos de la recepción de la noticia para la gente joven, entendiendo que se trata de una cuestión de gran relevancia en el actual momento de la transformación experimentada por la actividad periodística .

Palabras clave: los medios de comunicación, el consumo de noticias, universitarios

Esta obra está licenciada sob uma Licença Creative Commons

\section{Introdução}

Os jovens, faixa etária compreendida entre 15 e 24 anos de acordo com o Instituto Brasileiro de Geografia e Estatística (IBGE, 2010), constituem a maior faixa, percentualmente, da população brasileira, somando 50 milhões de pessoas. Embora o País esteja envelhecendo - percentual de brasileiros acima de 60 anos passou de 4,7\% da população em 1960 para 10,8\% em $2010^{1}$ - a juventude ainda é dominante. Dentro deste segmento, uma faixa tem apresentado crescimento significativo nas últimas décadas: os estudantes universitários que somavam, em 2012, 7,2 milhões de indivíduos, segundo o Censo da Educação Superior do Ministério da Educação (MEC, 2013). A pesquisa relatada neste artigo tem como foco justamente os estudantes universitários e procurou dimensionar seus hábitos de consumo de informação jornalística, detalhando com que frequência buscam notícias, quais meios utilizam para ter acesso a elas, em quais veículos noticiosos mais confiam e que assuntos despertam seu interesse.

Estudos recentes indicam que os índices de leitura de informações jornalísticas, sobretudo no meio digital, tem crescido. De acordo com o site Observatório da Imprensa, a “ideia de que jovens não são interessados em notícias pode estar errada. É o que revela uma nova pesquisa feita com donos de tablets no Reino Unido, que prevê um crescimento na leitura de notícias entre jovens de 18 a 24 anos" (HALLIDAY, 2013, p. 1). Também nos Estados Unidos levantamentos apontam que os jovens leem mais usando os dispositivos móveis. "Em 2012, segundo dados da Scarborough, 68\% dos adultos disseram ter consumido conteúdo de jornal nos últimos sete dias, digitalmente ou no impresso. É a mesma porcentagem do que em 2000. Agora, diversos dados - da Reynolds, Pew e outros - sugerem que o rápido crescimento de tablets e smartphones pode ajudar marcas de notícias conhecidas

\footnotetext{
${ }^{1}$ Dados do IBGE divulgados pelo Portal G1 em http://g1.globo.com/brasil/noticia/2012/04/em-50-anospercentual-de-idosos-mais-que-dobra-no-brasil.html. Acesso em 20/12/2013
} 
(...). Os dados da Pew Research sugerem, por exemplo, que a audiência do New York Times está maior, mais jovem e mais diversa devido ao digital" (Observatório da Imprensa, 2013).

No Brasil, o Dossiê Universo Jovem, pesquisa contratada pela MTV que em 2010 alcançou sua quinta edição englobando mais de duas mil entrevistas, indicou que $57 \%$ dos jovens leem notícias na internet (32\% o fazem "sempre" e 25\% "de vez em quando"); e 58\% leem jornais impressos (26\% "sempre" e 32\% "de vez em quando"). Se comparados aos levantamentos anteriores, os números apontam crescimento do consumo on line de notícias. Os índices de jovens que não buscam acesso a informações jornalísticas, no entanto, é alto no País: $31 \%$ nunca leem notícias na internet e $13 \%$ raramente o fazem; enquanto $25 \%$ informaram que nunca leem jornal impresso e $18 \%$ fazem isso raramente.

Pereira e Adghini ( 2011, p. 50) expõem outros dados, indicando um panorama de retração:

\begin{abstract}
Existe um mito generalizado de que o público das mídias tradicionais - sobretudo dos jornais - se retrai. Este cenário é agravado pela dificuldade de renovação da audiência, de constituição de um leitorado junto às novas gerações. Uma pesquisa do Pew Center realizada em 2002 mostra que o número de norte-americanos com menos de 25 anos que não utiliza nenhum meio de comunicação para se informar passou de $14 \%$ em 1994 para 37\% em 2002 (apud Huang, 2009). Estudo feito por Huang mostra que os jovens até consideram as notícias importantes, mas não priorizam o consumo de informações na divisão do seu tempo.
\end{abstract}

Estes indicadores reforçam a necessidade de que sejam ampliados os estudos em torno do tema, com vistas a colaborar no desenvolvimento de estratégias de motivação de leitura direcionadas à faixa de consumidores jovens. O jornalista Ricardo Noblat defende que o modelo de jornalismo praticado no Brasil está em xeque, sobretudo no meio impresso, "porque o medo de mudar é maior do que o medo de conservar algo que se desmancha no ar" (NOBLAT, 2002, p. 16). Ele elenca doze medidas que as empresas noticiosas deveriam adotar para enfrentar a crise, sendo a primeira: "renovar sua pauta de assuntos para ganhar mais leitores, principalmente mulheres e jovens" (idem). A pesquisa detalhada a seguir pretende contribuir neste debate em defesa do jornalismo, pois parte-se do pressuposto de que estamos tratando de uma atividade essencial para a manutenção de sociedades democráticas e para a construção de nações justas.

\title{
$A(s)$ juventude(s) e a notícia
}

A evolução das sociedades, ao longo da história humana, tem forjado maneiras diferentes de compreender e acolher as diversas faixas etárias. A juventude começou a ser 
identificada como fase específica da vida apenas por volta do século XIX, quando um conjunto de fatores contribuiu para alterar o olhar da sociedade para a etapa que separava a infância do mundo adulto: o aumento da escolaridade, a legislação relativa ao trabalho infantil, o surgimento da família de caráter privado, entre outros. "Para discutir o que vem a ser a juventude é necessário começar desmistificando-a como categoria apenas natural e biológica, quando na verdade ela é, sobretudo, uma construção social que varia de acordo com as diferentes culturas e mesmo no interior de cada cultura - e que nem sempre existiu como categoria socialmente visível" (CATANI e GILIOLI, 2008, p. 12/13).

Por isso, os autores falam em juventudes, no plural, salientando que mesmo no interior de uma dada estrutura social convivem diferentes maneiras de ser jovem, cujas condições são ditadas, entre outros, por aspectos socioeconômicos, culturais, étnicos e educacionais.

\footnotetext{
Para a sociologia, a juventude emerge como tema relevante por ser fenômeno típico da sociedade moderna. Enquanto nas sociedades ditas tradicionais identificam-se marcos claros na passagem na infância para a vida adulta (muitas vezes sem períodos intermediários), as sociedades modernas caracterizam-se por ter a juventude como fase transitória entre a condição infantil e adulta, mas sem limites precisos e não demarcados por rituais sociais rígidos (CATANI e GILIOLI, 2008, p.15).
}

É a partir do século XX que as diversas correntes sociológicas se debruçam sobre o fenômeno da juventude, algumas vezes com posturas divergentes - oscilando entre a Escola de Chicago, que nos anos 1920 e tomando como base a Psicologia, encarava a juventude como problema, até a linha dos Estudos Culturais, datada da década de 60, que enfatiza a diversidade das condições juvenis e abandona a noção de jovens homogêneos. "É necessário dizer que não há apenas uma juventude e uma cultura juvenil, mas várias, que diferem segundo condições sociais e históricas específicas” (CATANI e GILIOLI, 2008, p.11).

Na segunda metade do século, a urbanização crescente levou o debate de políticas públicas para a juventude a posições de destaque, promovendo investimentos governamentais, em muitos países, nos setores de educação, qualificação de mão de obra, cultura, lazer, esportes, com objetivo de atender a esta faixa etária. Da mesma forma, os jovens começaram a figurar como protagonistas nos segmentos de moda, música, games, aparelhos eletrônicos e outros, confirmando a juventude como importante mercado consumidor.

Estudos de disciplinas nos mais diversos ramos do conhecimento passaram a privilegiar a juventude como foco, reconhecendo suas especificidades, sua identidade múltipla e não mais escamoteando os conflitos que são típicos desta etapa. A sociedade como um todo, os governos e os próprios jovens entendem hoje, majoritariamente, a juventude como sujeito 
de direitos e não apenas como uma fase transitória entre a criança e o adulto: "Pode-se dizer que para a sociedade o desafio é definir o jovem e para o jovem é definir-se diante de si próprio, de seus pares e perante a sociedade" (CATANI e GILIOLI, 2008, p. 12)

Ao tratar das relações entre juventude e jornalismo, Karan (2010, p. 235) indaga: “A juventude, as rede sociais e o jornalismo estariam hoje em nova etapa de compartilhamento de valores... e de outros valores?" Para o autor, dentro de uma sociedade complexa, o jornalismo tende a ser mais complexo, mais segmentado em termos de público e especializado quanto aos assuntos tratados. Ele diferencia as produções de conteúdo fartamente disponibilizadas no irrestrito ciberespaço, da produção jornalística centrada nos pilares da profissão, quais sejam: a defesa do interesse coletivo, o comportamento ético e a qualidade técnica do material veiculado. No entanto, para o autor, "o velho e bom jornalismo" tem condições plenas de atender as demandas dos diferentes nichos de jovens e do que significa ser jovem:

E isto ocorre a partir de três perspectivas complementares: a) a especificidade da práxis profissional jornalística que remete à reflexão e produção; b) o atendimento à demanda do que se chamaria Juventude em termos de novas mídias e novas linguagens em novos suportes tecnológicos; c) a inclusão participativa, com produção de conteúdos, do que se chamaria Juventude na confecção tanto da especificidade profissional quanto de novas linguagens e novas mídias em novos suportes tecnológicos (KARAN, 2010, p. 244).

Este olhar para o potencial informativo do jornalismo direcionado aos jovens não anula, como reforça o autor, os preceitos históricos da profissão e suas matérias-primas essenciais, entre as quais está a notícia, um dos fenômenos que dão reconhecimento público e social ao jornalismo, pois carrega as marcas dos processos de produção, dos sentidos do mundo aplicados a ela pelos jornalistas e dos sentidos que são atribuídos pelos leitores. A notícia materializa o vínculo social que o jornalismo produz, ligando pessoas a fatos, situações e temas propostos à apreciação das comunidades e contribuindo para a formação da opinião pública.

Entendida contemporaneamente como fato verdadeiro, atual e capaz de atrair o interesse público, notícias são definidas por Jorge Pedro de Sousa (2002, p. 23) como

... artefatos lingüísticos que procuram representar determinados aspectos da realidade e que resultam de um processo de construção e de fabrico onde interagem, entre outros, diversos fatores de natureza pessoal, social, ideológica, cultural, histórica e do meio físico/tecnológico, que são difundidos pelos meios jornalísticos e aportam novidades com sentido compreensível num determinado momento histórico e num determinado meio 
sociocultural (ou seja, num determinado contexto), embora a atribuição última de sentido dependa do consumidor da notícia.

A citação contempla variados elementos capazes de contribuir para explicar "por que as notícias são como são", na expressão do autor, e deixa claro um aspecto importante - ao qual nem sempre as teorias do jornalismo atribuem a devida atenção -: o papel do público na elaboração final do sentido da informação jornalística. Apenas diante desta formação de sentido, aquilo que foi lido, ouvido ou assistido nos veículos noticiosos pode ser compreendido pelos consumidores e pode ser utilizado em suas vidas. Afinal, "a principal finalidade do jornalismo é fornecer aos cidadãos as informações do que necessitam para serem livres e se autogovernar" (KOVACH e ROSENSTIEL, 2004, p. 31).

\section{Detalhamento da Pesquisa}

As definições relativas à pesquisa sobre hábitos de consumo de notícias por estudantes universitários curitibanos foram tomadas em sala de aula, em um processo de formação de consenso - conduzido pela professora responsável - entre as turmas dos períodos da manhã e da noite, da disciplina Pesquisa em Jornalismo, integrante da grade do terceiro ano do curso de Jornalismo da Universidade Positivo.

Identificado o tema e o foco do trabalho, várias equipes foram formadas para tarefas específicas: cálculo da amostra; contatos com as instituições de ensino; elaboração dos questionários; realização de levantamentos bibliográficos para esclarecimento do "estado da arte" em relação a temáticas como leitura entre jovens, consumo de informação jornalística e impactos das novas tecnologias no segmento, entre outras.

$\mathrm{O}$ primeiro consenso foi que a pesquisa deveria ser feita junto a universitários matriculados em cursos distantes das áreas da comunicação - considerando-se que, pelo menos teoricamente, os futuros comunicadores teriam maior compromisso com a informação de atualidade. Definiu-se a seguir que seriam pesquisados estudantes de Direito e Engenharia Civil, dois cursos de áreas distintas e com grande número de ofertas em Curitiba, o que poderia facilitar o acesso: são sete instituições na cidade que mantém cursos de Engenharia Civil, e nada menos do que 16 de Direito.

A montagem dos instrumentos de pesquisa foi a etapa mais longa e debatida, primeiro para estabelecer os questionamentos necessários para alcançar os objetivos propostos e, em segundo lugar, para criar um mecanismo de aferição das respostas - sistemática consubstanciada em um segundo questionário, denominado 'de aferição'. O primeiro 
questionário compreendia 21 questões objetivas, cinco das quais implicavam desdobramentos (pedindo, por exemplo, que o estudante numerasse, de um a dez, em ordem crescente, os meios que mais utilizavam para ter acesso a informações; ou os assuntos que mais interessavam). As cinco últimas questões incluíam dados de identificação dos respondentes como idade, renda familiar e outros. $\mathrm{O}$ segundo questionário, detalhado mais adiante, foi formulado a partir de notícias veiculadas na mídia nas 72 horas anteriores à aplicação.

A aplicação da pesquisa foi feita entre 30 de abril e 7 de junho de 2013 em duas turmas, nos turnos da manhã e noite, dos cursos de Direito e Engenharia Civil da Universidade Positivo e da Universidade Federal do Paraná. No Complexo de Ensino Superior do Brasil (Unibrasil) responderam à pesquisa apenas estudantes do curso de Direito, pois a instituição não oferece Engenharia Civil e, finalmente, na Faculdade Educacional Araucária (Facear) foram pesquisados os alunos do curso de Engenharia Civil noturno. No total, 470 universitários responderam os instrumentos de pesquisa: 56\% matriculados em cursos de Direito e 44\% em Engenharia Civil. Houve uma concentração expressiva de estudantes do primeiro ano ( $78 \%$ do total), em função da facilidade de acesso às turmas; $16 \%$ cursavam o segundo ano e $6 \%$ o quarto ano.

A predominância de calouros justificou a idade média da amostra, fixada em 21 anos: $37 \%$ dos pesquisados que informaram a idade tinham até 18 anos; $16 \%$ entre 19 e 20 anos; $19 \%$ de 21 a 25 anos e $12 \% 26$ anos ou mais. 49,1\% deles trabalhavam no momento em que responderam a pesquisa e 51,9\% não estavam atuando no mercado de trabalho. Os estágios ou empregos na área de formação correspondiam a 27\% das ocupações identificadas.

Ao responderem onde tinham estudado a maior parte do ensino fundamental e médio $51 \%$ indicaram as escolas privadas e $47 \%$ escolas públicas (2\% não informaram e $1 \%$ indicou ter estudado em ambas, escolas públicas e privadas). $65 \%$ cumpriram estas etapas escolares em Curitiba; $13 \%$ na Região Metropolitana; $12 \%$ em cidades do interior do Paraná e 10\% em outros estados (1\% não informou).

Duas outras questões foram feitas aos entrevistados com objetivo de clarificar a composição da amostra, uma sobre renda familiar e outra a respeito do nível de escolaridade dos pais. As respostas então nos gráficos I e II abaixo:

\section{Gráfico I - Renda Familiar}




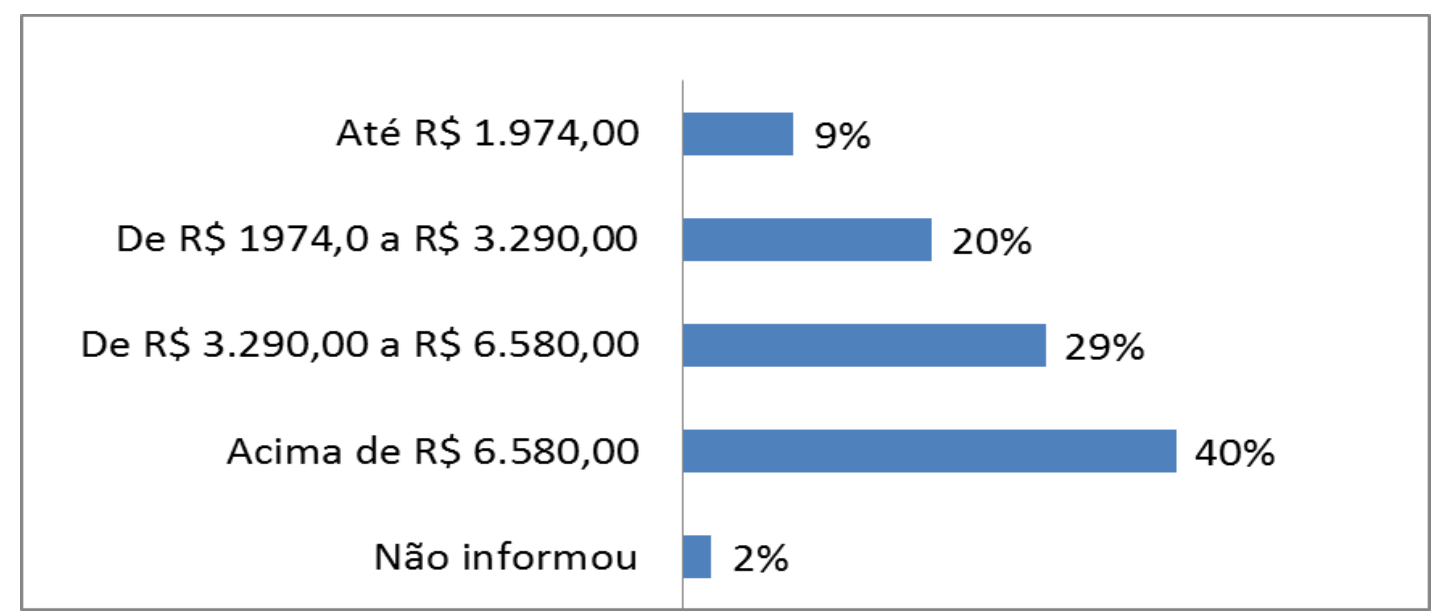

Fonte: da autora

Os dados comprovam que o acesso ao ensino superior ainda não é uma realidade para toda a juventude brasileira. A situação socioeconômica familiar é determinante no estabelecimento de oportunidades de educação. Quase 70\% dos respondentes indicaram renda familiar acima de dez salários mínimos. Estes números corroboram os resultados do Dossiê MTV (2010, p. 18): “54\% dos jovens com mais de 18 anos só estudaram até o ensino médio. O acesso à universidade continua sendo maior na classe A (39\%), em comparação com a média da população jovem entrevistada nesse estudo (11\%)".

Outro dado de identificação relacionava-se à escolaridade dos pais, pois considera-se que a educação formal é um elemento importante na formação do hábito de leitura, inclusive de notícias, e que o exemplo familiar reflete-se no comportamento do jovem.

\section{Gráfico II - Escolaridade dos Pais}




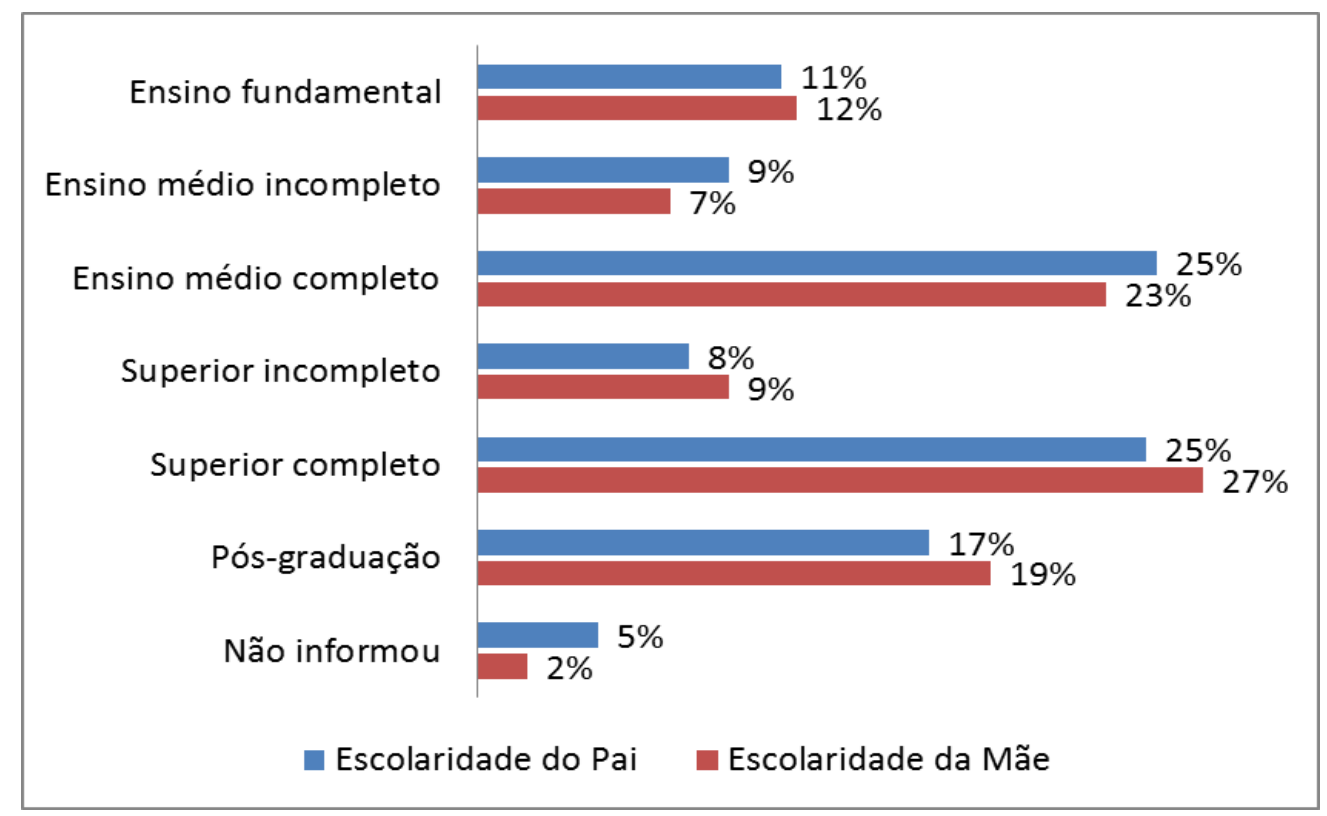

Fonte: da autora

Mais da metade dos entrevistados têm genitores que concluíram o ensino médio ou o ensino superior. As mães apresentavam grau de escolaridade ligeiramente acima dos pais quando chegavam aos bancos das universidades: $27 \%$ delas têm ensino superior completo, contra $25 \%$ dos pais e $19 \%$ das mães têm pós-graduação, contra $17 \%$ dos pais. Se a comparação for feita entre instituições de ensino, é possível verificar que os estudantes da Universidade Federal do Paraná têm pais com nível de escolaridade, em média, superior aos universitários das instituições privadas.

\section{Apresentação dos Dados}

Foram aplicados dois instrumentos de pesquisa ao universo de estudantes que aceitaram participar do levantamento. O primeiro, composto por 21 questões, incluía em seu final os dados de identificação dos respondentes mencionados no item anterior, e buscava identificar os hábitos de consumo de notícias sob variados aspectos que serão detalhados na sequência.

O segundo questionário, de aferição, foi montado com objetivo de tentar comprovar o conhecimento efetivo dos estudantes em relação às notícias. Este instrumento foi alterado seis vezes ao longo do período de aplicação da pesquisa, sempre contemplando perguntas de variadas áreas (política nacional e internacional, economia, cultura, esporte etc) baseadas em informações jornalísticas divulgadas nos dois ou três dias anteriores. Na tabulação deste questionário levou-se em conta apenas o número de acertos e erros de cada questão, não seu conteúdo. 
A indagação de abertura do primeiro questionário estava assim formulada: "Você busca se informar sobre notícias por qualquer meio de comunicação?”

\section{Gráfico III - Hábito de consumo de informação jornalística}

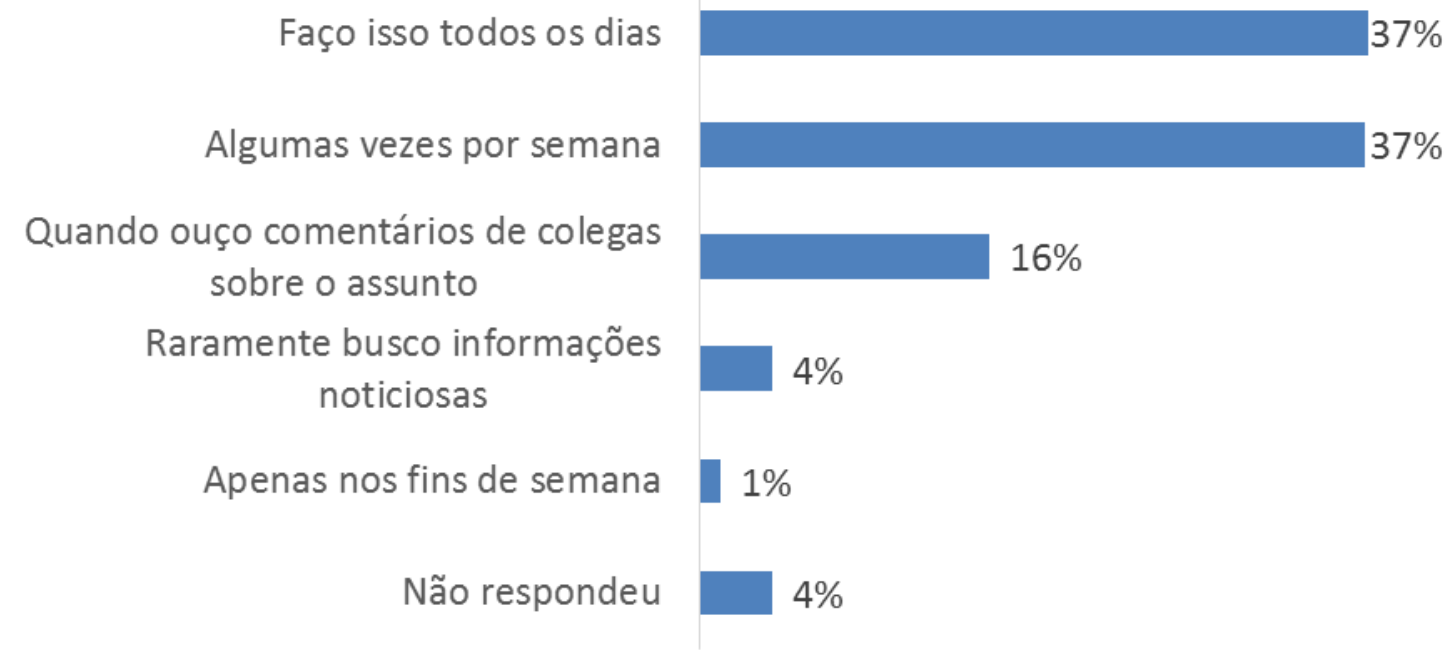

Fonte: da autora

Os dados coletados junto aos universitários curitibanos indicam um percentual maior de entrevistados interessados em notícias do que os índices identificados no Dossiê Universo Jovem, citado anteriormente, ou mesmo os levantamentos efetuados nos Estados Unidos. Estes grupos, na verdade, não eram integrados apenas por estudantes de ensino superior, o que pode justificar a diferença, pelo menos parcialmente ${ }^{2}$. De qualquer maneira, $74 \%$ dos entrevistados - quase dois terços do total - buscam notícias com regularidade, diariamente ou algumas vezes por semana. Apenas $4 \%$ informaram que raramente leem notícias, enquanto $16 \%$ procuram informações quando sentem-se motivados por comentários de outras pessoas a respeito de algum assunto. Este dado corrobora uma conhecida teoria da comunicação, a teoria do agendamento, que indica a capacidade da mídia em pautar as conversas na sociedade

\footnotetext{
${ }^{2}$ Outra hipótese pode estar relacionada aos aplicadores da pesquisa. Como os estudantes estavam respondendo para colegas universitários do curso de Jornalismo, pode-se considerar a possibilidade de terem manifestado um interesse maior do que o real em relação à busca por informações jornalísticas, no sentido de responder o que eles sabiam que os entrevistadores gostariam de ouvir. Esta distorção nos instrumentos de pesquisa é admitida por vários pesquisadores. Duarte (s/d), citando Kandel (1981, p.178) lembra que a entrevista em pesquisa "não é simplesmente um trabalho de coleta de informações, mas, sempre, uma situação de interação, ou mesmo de influência entre dois indivíduos e que as informações dadas pelo sujeito (o material que ele fornece) podem ser profundamente afetadas pela natureza de suas relações com o entrevistador". No artigo Compreender, do volume Miséria do Mundo (2007), Bourdieu trata da relação social que se estabelece entre pesquisadores e pesquisados, salientando os efeitos derivados desta situação de poder / submissão.
} 
contemporânea. O mais conhecido enunciado desta corrente teórica foi formulado por Cohen: "Embora a imprensa, na maioria das vezes possa não ser bem sucedida ao indicar às pessoas como pensar, é espantosamente eficaz ao dizer a seus leitores sobre o que pensar" (citado por MCCOMBS e SHAW, 2000, p.49).

Logo em seguida, os entrevistados eram convidados a numerar de um a dez, em ordem crescente, os meios que mais utilizavam para ter acesso a informações. O gráfico IV, abaixo, mostra a informação ponderada das 470 respostas $^{3}$.

\section{Gráfico IV - Informação ponderada dos veículos mais usados na busca por notícias}

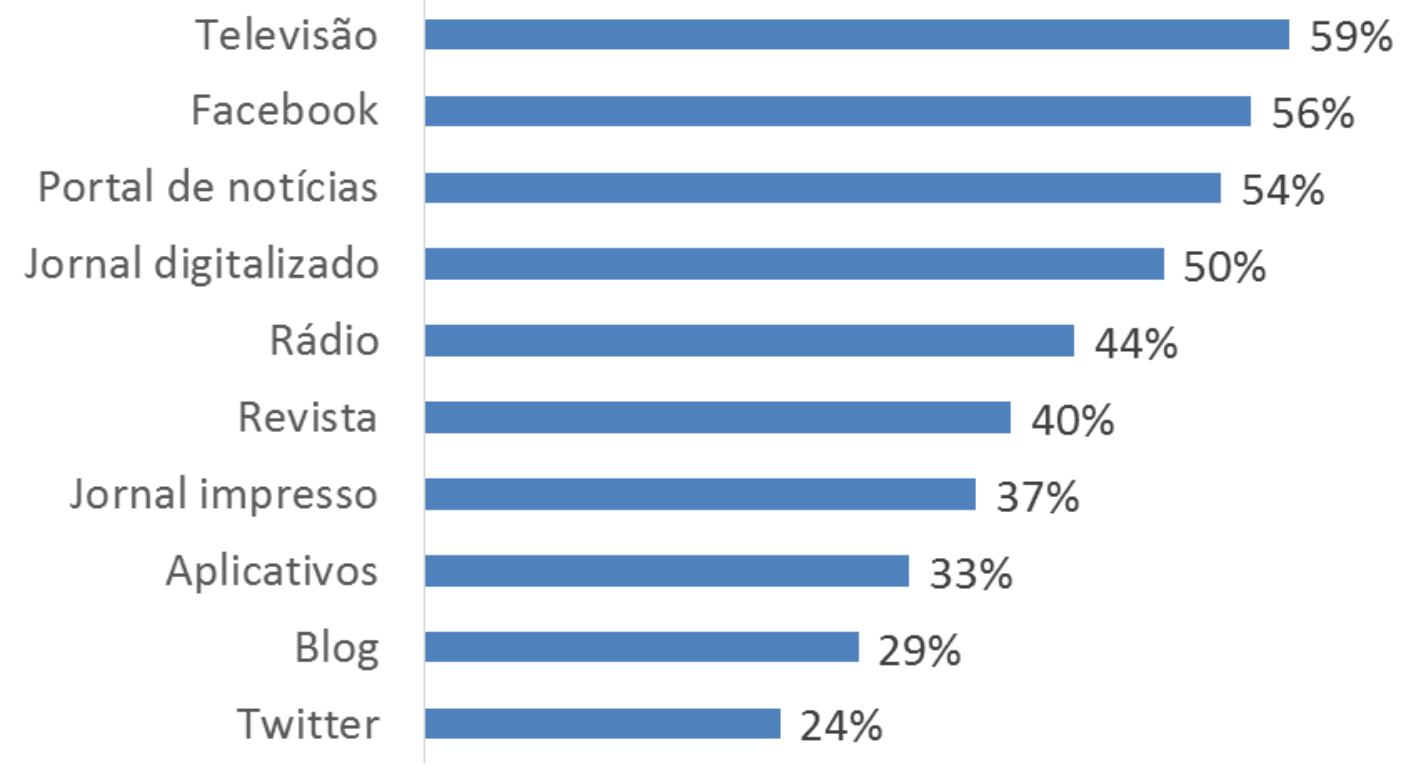

Fonte: da autora

A televisão é identificada há várias décadas como o principal veículo de informação da população brasileira. Aparelhos de tevê estão presentes em mais de $98 \%$ dos domicílios do país, de acordo com dados do IBGE (2010) e a prevalência do meio é constatada em afirmações como de Resende (2000, p. 23), para quem, a televisão "assume a condição de única via de acesso às notícias e ao entretenimento para grande parte da população”. Os dados da tabela, no entanto, indicam que as tecnologias digitais, apesar de seu desenvolvimento recente, ocupam espaço rapidamente. Apenas três pontos abaixo da televisão aparece o facebook ${ }^{4}$ como primeira forma de obter informação e dois outros meios

\footnotetext{
${ }^{3}$ No cálculo da Informação ponderada é atribuído um peso para cada resposta, por exemplo, número de citações em primeiro x 10 + número de citações em segundo x 9 e assim por diante até a décima citação.

${ }^{4}$ Não se pretende aqui discutir o entendimento do facebook como meio de informação noticiosa - embora exista um amplo consenso entre os teóricos da comunicação de que isso efetivamente não ocorre - mas apenas ressaltar 
acessados pela rede mundial de computadores (portal de notícias e jornal digitalizado) figuram com mais de $50 \%$ na informação ponderada entre os respondentes.

A terceira indagação do questionário buscava identificar o índice de confiança atribuído aos vários meios de comunicação. A informação ponderada apontou os resultados indicados no Gráfico V:

\section{Gráfico V - Informação ponderada sobre o nível de confiança dos veículos noticiosos}

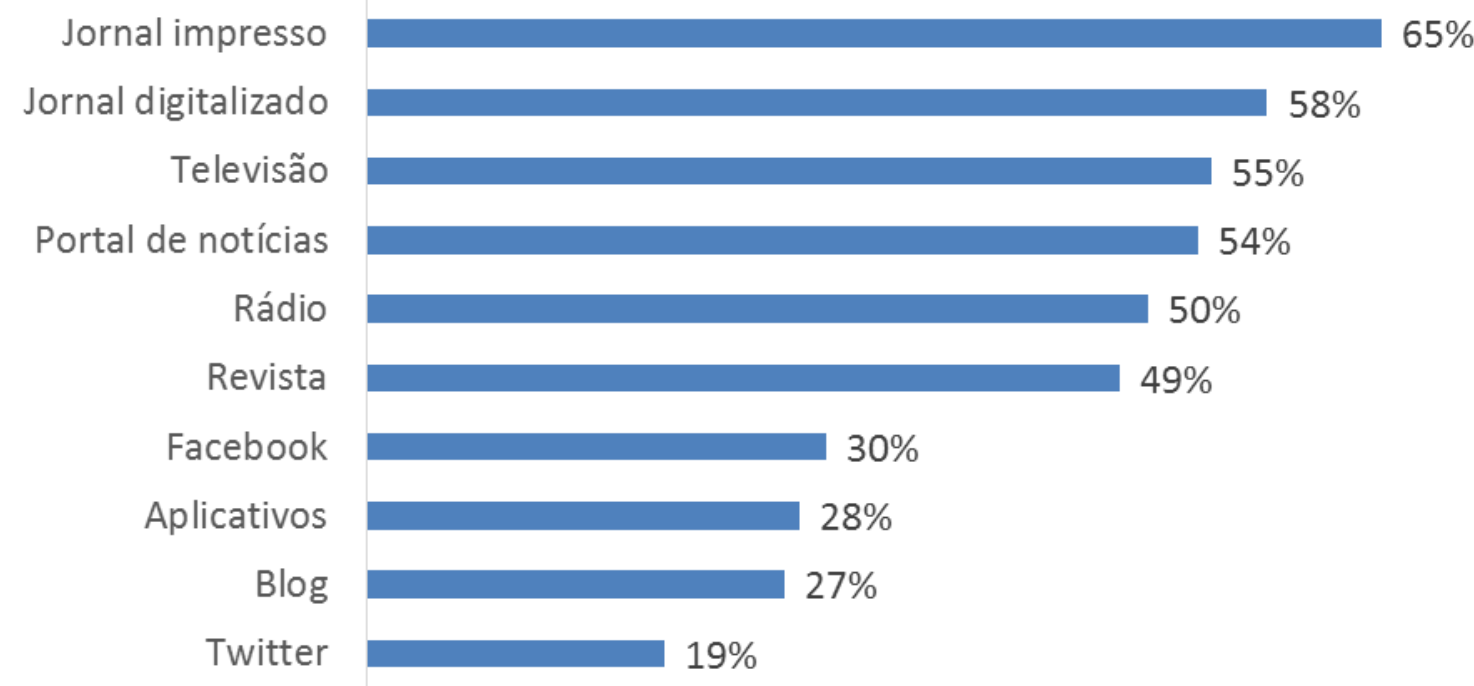

Fonte: da autora

Embora o jornal impresso figure apenas em sétimo lugar na tabela ponderada do primeiro meio consultado em busca de notícias, seu índice de confiabilidade é o mais alto (com 65\%), ficando a tevê - que aparece como primeiro meio utilizado na busca de informações - em terceiro lugar no quesito confiança (55\%) e o facebook em sétimo como veículo confiável (30\%), tendo alcançado a segundo colocação entre os meios usados para informação. O jornal digitalizado, com 58\%, aparece como segundo mais confiável reafirmando a percepção dos respondentes no sentido de que o veículo mais tradicional do jornalismo goza de ampla credibilidade.

A confiança do jornal impresso é confirmada em outros levantamentos. O Dossiê Universo Jovem, da MTV, identificou tendência semelhante: "No geral, os jovens não ousam

o fato de que os universitários curitibanos identificam na rede social uma significativa forma de acesso aos acontecimentos de atualidade. No Dossiê Universo Jovem encontra-se o seguinte: "Não gosto de usar a palavra mídia, pois não gosto de usar palavras das quais não entendo o significado. Antes dos automóveis existirem, falávamos sobre carruagens. Hoje, existem algumas palavras que estão sendo muito desafiadas em seu significado, como 'mídia' e 'jornalismo'. Se eu leio uma notícia num blog, isso é jornalismo? Será que quem escreveu a notícia é um jornalista? Para mim essas definições não funcionam mais. O que é mídia? A internet é mídia? E o Facebook é uma mídia?" (Chris Anderson, editor da revista Wired Magazine e autor do livro Long Tail) (Dossiê, 2010, p.26) 
contestar a qualidade das notícias, a seriedade e a confiabilidade do jornal impresso. Demonstram respeito pelo jornal, e há até sentimento de culpa por parte dos que gostariam de ser mais interessados em ler, pois consideram o jornal um meio importante, que traz qualidade de informação, isenção de opiniões e conhecimento (DOSSIÊ, 2010, p.54).

Mamede e Pedroza (2009, p. 75) também evidenciaram o reconhecimento dado ao jornal impresso:

\begin{abstract}
Apesar do advento do telejornal e mais recentemente do jornal on-line, o jornal impresso mantém uma posição consolidada sobressaindo-se por sua expressão de análise, pois graças ao "tempo" entre o fato e a notícia, pode apresentar opiniões diversas contribuindo ainda mais para a polêmica. Os temas que transitam nos meios de comunicação são os que transitam na sociedade. O tema pode ser apresentado sob diferentes abordagens, atendendo ao enfoque predominante do grupo. (...)Embora as novas mídias tenham forte presença do cotidiano dos jovens, nossa pesquisa ratifica a permanência do jornal impresso como fonte de informação para o jovem.
\end{abstract}

Da mesma forma, sondagem feita junto a 69 estudantes do curso de Comunicação Social da Universidade Federal de Minas Gerais em 2005 aponta o índice maior de confiabilidade no jornal impresso. De acordo com Jhonson (2007, p. 9/10), embora a maioria dos respondentes tenha afirmado que a Internet era o meio de comunicação usado com mais frequência para se manterem informados sobre as notícias do dia-a-dia, esse meio foi justamente citado como o que eles menos confiam (37,7\%); em segundo lugar veio a TV (30,4\%). O meio de comunicação em que os jovens universitários mais confiam é o jornal impresso, com $39,1 \%$ das preferências.

$\mathrm{Na}$ quarta pergunta do questionário respondido pelos universitários curitibanos os estudantes foram indagados a respeito da plataforma que usam para ler jornal, quando o fazem: $10 \%$ disseram que não leem; $29 \%$ disseram ler no formato impresso; $59 \%$ optaram pelos sites e $7 \%$ indicaram que optam pela versão disponibilizada para tablets - novamente confirmando o predomínio dos mais recentes meios de acesso a informações.

\title{
Mídia eletrônica
}

O Gráfico VI mostra as respostas a respeito do hábito de ouvir rádio pelos 470 entrevistados:

\section{Gráfico VI - Frequência com que ouve rádio}




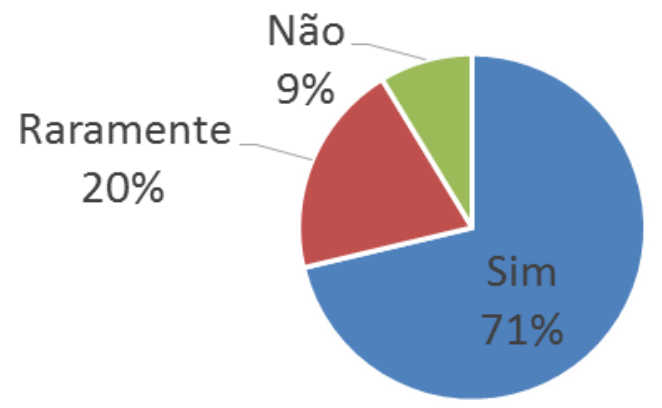

Fonte: da autora

Dos 335 entrevistados que costumam ouvir rádio, 74\% usam o veículo para ouvir música; $43 \%$ ouvem notícias e $18 \%$ procuram programas de esportes. O percentual, somado, é superior a 100\% porque era admitida mais de uma resposta nesta questão.

No levantamento efetuado entre universitários do curso de Comunicação Social em Belo Horizonte, (Johnson, 2007) os dados demonstraram que o rádio é o veículo de comunicação menos utilizado: $15,9 \%$ responderam que "nunca" utilizam o rádio como meio de busca de informação sobre a atualidade, enquanto $37,7 \%$ disseram que usam "raramente" e outros 23,2\% indicaram “de vez em quando". Em Picos, na Paraíba, pesquisa feita com 76 jovens universitários de variados cursos apontou que $69 \%$ dos respondentes revelaram não utilizar o rádio como meio noticioso, já $27 \%$ afirmaram se informar por esse meio de comunicação, devido à transmissão de acontecimentos locais (BEZERRA e TORRES, 2011, p.9). “A superficialidade e a falta de diversificação dos fatos também é um dos fatores para o desinteresse juvenil frente ao rádio informativo", dizem as autoras (idem, p. 10). O rádio aparece como companheiro no trânsito e, de acordo com Chaves (2012), é utilizado mais por jovens aficionados pelo esporte, em especial o futebol.

Já $80 \%$ dos integrantes da amostra curitibana assistem à televisão costumeiramente e $20 \%$ o fazem raras vezes. Quase um terço dos 374 pesquisados que disseram assistir tevê, ou $32 \%$ do total, não informaram seus programas de preferência. Entre os que o fizeram, como indica o Gráfico VII, 45\% indicaram os noticiários em primeiro lugar; 44\% os programas de entretenimento e, como no caso do rádio, $18 \%$ buscam programas esportivos.

\section{Gráfico VII - Preferência por programas televisivos \\ (somatória superior a $100 \%$ por que havia possibilidade de escolhas múltiplas)}




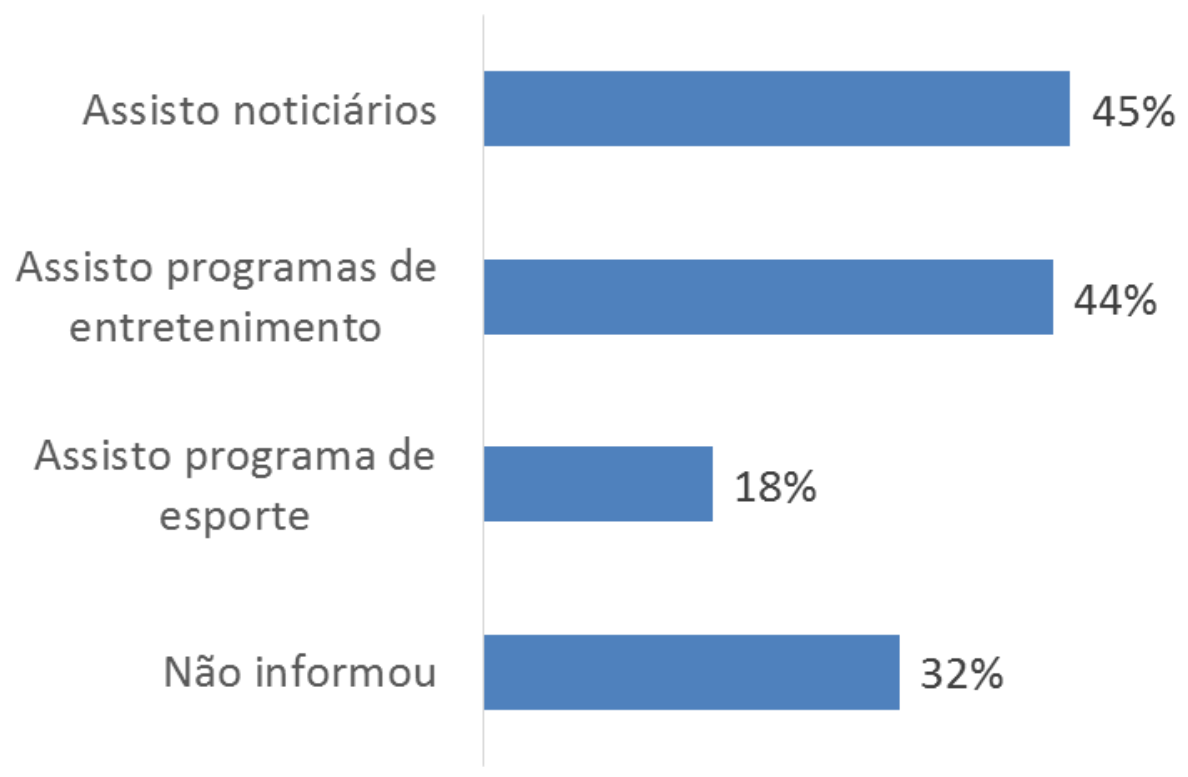

Fonte: da autora

Estes indicadores, apontando que os estudantes de Curitiba usam a tevê preferencialmente em busca de informação jornalística não concordam com os resultados da pesquisa Dossiê Universo Jovem, que apontou a televisão, assistida por $100 \%$ dos entrevistados, como elemento de lazer:

O jovem brasileiro tem uma ligação emocional com a TV, que representa um momento de relaxamento, descanso e conforto, remetendo a uma passividade positiva.(...) O jovem pensa na TV como um meio de comunicação que lhe faz companhia quando está sozinho, além de a considerar um elemento que agrega a família e os bons amigos. Ela representa, para essa geração, o que a fogueira representou para as sociedades tribais - um momento-família, seja a família sanguínea ou a dos melhores amigos. No entanto, diferentemente dos tempos em que famílias se reuniam em volta da fogueira para trocar experiências, hoje, quando os jovens assistem TV com suas famílias, há pouco espaço para a conversa, para a troca, pois o conteúdo da programação se torna o centro das atenções (DOSSIÊ, 2010, p.47).

Estes dados provocaram um saudável debate em sala, durante a apresentação dos resultados do levantamento feito aos pesquisadores. Alguns alunos consideraram que a maior preferência pelos noticiários manifestava apenas uma tendência de "ser simpático" ao entrevistador/estudante de jornalismo. Outros reconheceram que os universitários muitas vezes têm ritmos de vida atribulados e pouco tempo disponível para o lazer, entendido aqui 
como os programas de entretenimento - em que pese o fato da diferença entre as duas opções ter sido de apenas um ponto percentual na contagem final dos questionários.

Os respondentes foram inquiridos também a respeito do hábito de lerem notícias em site. O Gráfico VIII, abaixo, mostra as respostas:

\section{Gráfico VIII - Consumo de notícias em sites}

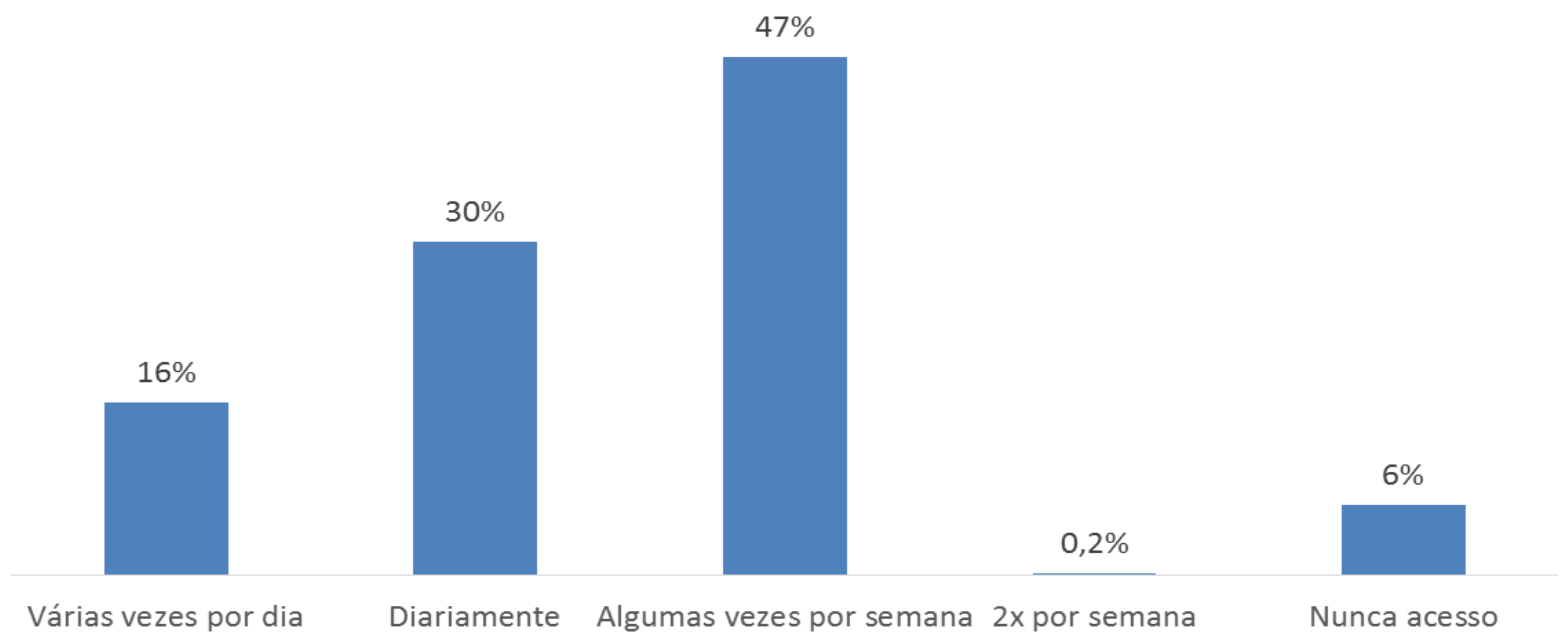

Fonte: da autora

Quando indagados a respeito do hábito de acessar sites de notícias apenas $6 \%$ declararam não acessar. Quase metade dos 470 entrevistados (46\%) leem notícias on line diariamente ou várias vezes por dia. A realização de atividades na internet é uma realidade plenamente estabelecida para esta geração.

A atual geração de jovens nasceu 'conectada', de modo que a linguagem dos meios digitais é praticamente inerente ao seu cotidiano - guardadas as devidas proporções no que se refere às possibilidades de acesso. Soma-se a isso o fato da juventude corresponder a um perfil do consumidor, uma nova fatia de mercado, cujos integrantes passam a ser vistos como cidadãos em função do seu elevado potencial de consumo (SCHLAUCHER, 2012, p.08).

De acordo com o Dossiê Universo Jovem, 60\% dos jovens acham que quem não acessa a internet fica desatualizado e não tem assunto para conversar com os amigos.

A internet é onipresente. Traz entretenimento, diversão, notícia, informação e conhecimento em tempo real, além de ajudar nos estudos e no trabalho, de uma forma prática e confortável. Ela também ajuda na socialização, no contato com quem está distante, permite encontrar pessoas, fazer novas amizades. Mas o principal benefício da internet, para o jovem, é a interatividade: a possibilidade de agir e interagir, de participar, de estar no comando e de fazer acontecer. Nesse ponto, ela é um canal totalmente 
diferente da TV, que é vista como um meio mais passivo, usado para relaxar, distrair e descansar (DOSSIÊ, 2010, p.40).

Ao mesmo tempo, acrescenta o relatório, esses usuários têm consciência de que a internet é um meio que os torna muito vulneráveis. Os principais pontos negativos estão relacionados à falta de segurança: golpes, crimes, pedofilia, informações falsas, vírus, invasões nas páginas de sites de relacionamento e falta de privacidade. "Também reconhecem que não percebem o tempo passar quando estão on-line: vão de um site para outro e acabam ficando conectados mais tempo do que gostariam, o que os faz se sentir presos, abduzidos, dependentes demais da internet. Os longos períodos que o jovem passa na web não significam, necessariamente, um tempo em que ele está ganhando aprendizado, conhecimento ou mesmo produtividade" (idem, p.41).

Ainda segundo o Dossiê Universo Jovem, no caso das notícias, a migração do impresso para a internet já aconteceu para 6 em cada 10 jovens. "Ler notícias no papel é mais eventual, geralmente nos fins de semana, para dar uma olhada nas seções de esporte, lazer, classificados de empregos e compras. Eles leem os jornais dos pais e avós, para dar uma olhada, quando não têm outro meio disponível" (DOSSIÊ, 2010, p. 54).

Embora a internet apareça como elemento de socialização e interatividade, mais de $60 \%$ dos universitários curitibanos ouvidos na pesquisa optaram pelas alternativas 'nunca' ou 'raramente' ao serem indagados se compartilham notícias nas redes sociais. Em relação ao índice de leitura das notícias compartilhadas que recebem, $20 \%$ disseram que 'raramente' ou 'nunca' leem, 7\% informaram que 'sempre' o fazem e 73\% consideraram que a leitura, ou não, depende do assunto (89\%) e do site (24\%).

\section{Gráfico IX - pagaria para ter acesso à informação? Paga atualmente?}




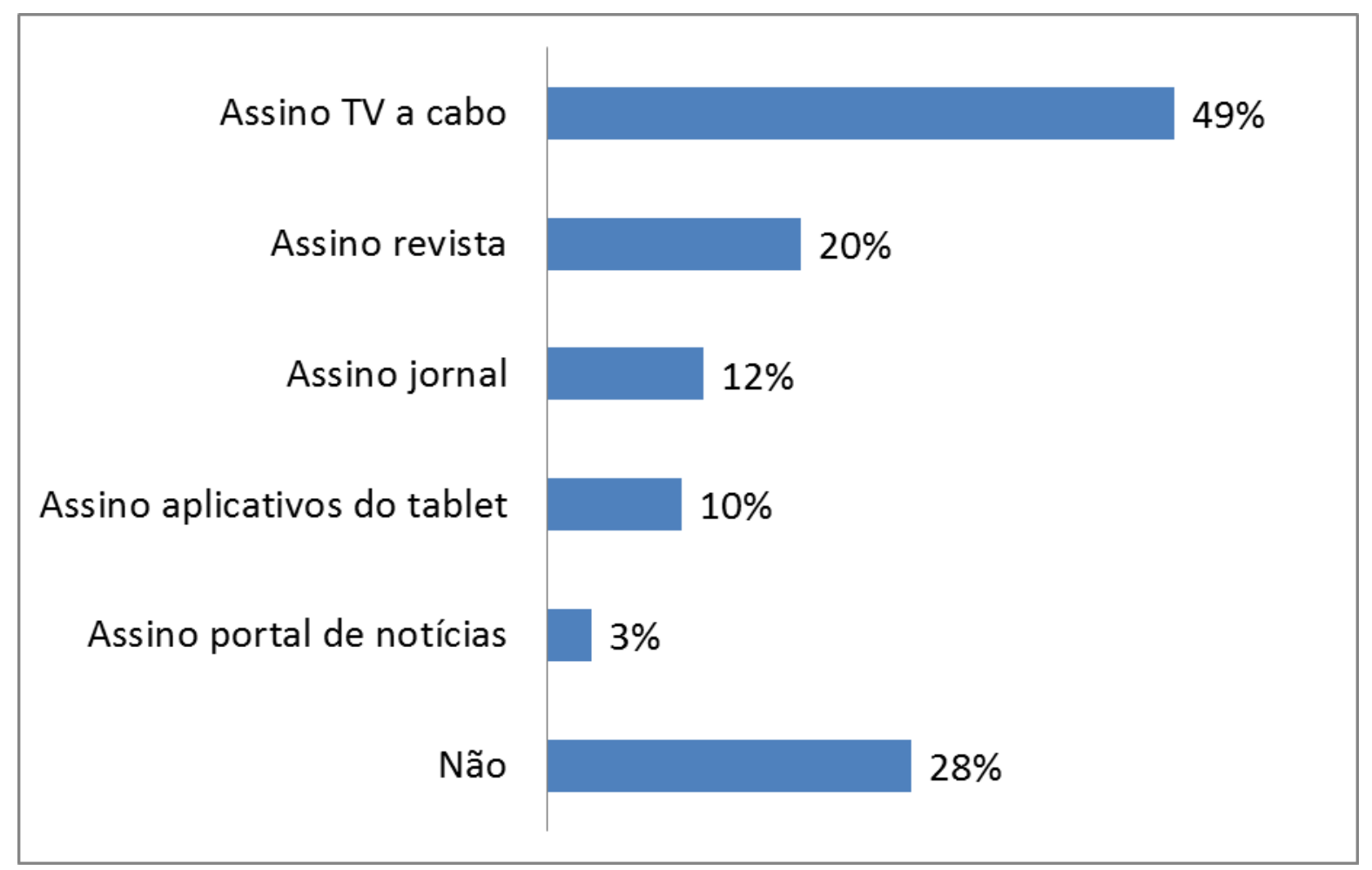

Fonte: da autora

Quase um terço dos entrevistados (28\%) afirmou que não pagaria para ter acesso a informações jornalísticas, conforme demonstra o Gráfico IX, acima. Hoje, 49\% disseram que em suas residências existe assinatura de TV a cabo; $20 \%$ têm assinatura de revistas; $12 \%$ de jornal impresso e $10 \%$ assinam aplicativos para tablets. A despeito do fato que a TV a cabo poder ser utilizada sobretudo para entretenimento e que a pesquisa não solicitou a identificação das revistas que são assinadas pelos respondentes - assim como os aplicativos para tablets - presume-se, pelos dados acima, que existe uma disposição majoritariamente significativa de remunerar os veículos informativos, reconhecendo que a produção e distribuição de notícias é um serviço desempenhado por um segmento econômico e que, portanto, necessita contrapartida dos consumidores.

A pesquisa desenvolvida junto a universitários curitibanos procurou aferir ainda os assuntos que mais interessavam aos respondentes quando buscavam informações jornalísticas. Eles deveriam numerar, de um a dez, por ordem crescente de interesse entre uma lista de editorias. Os resultados estão no Gráfico X. 


\section{Gráfico X - Assuntos que mais interessam na busca por notícias (informação ponderada)}

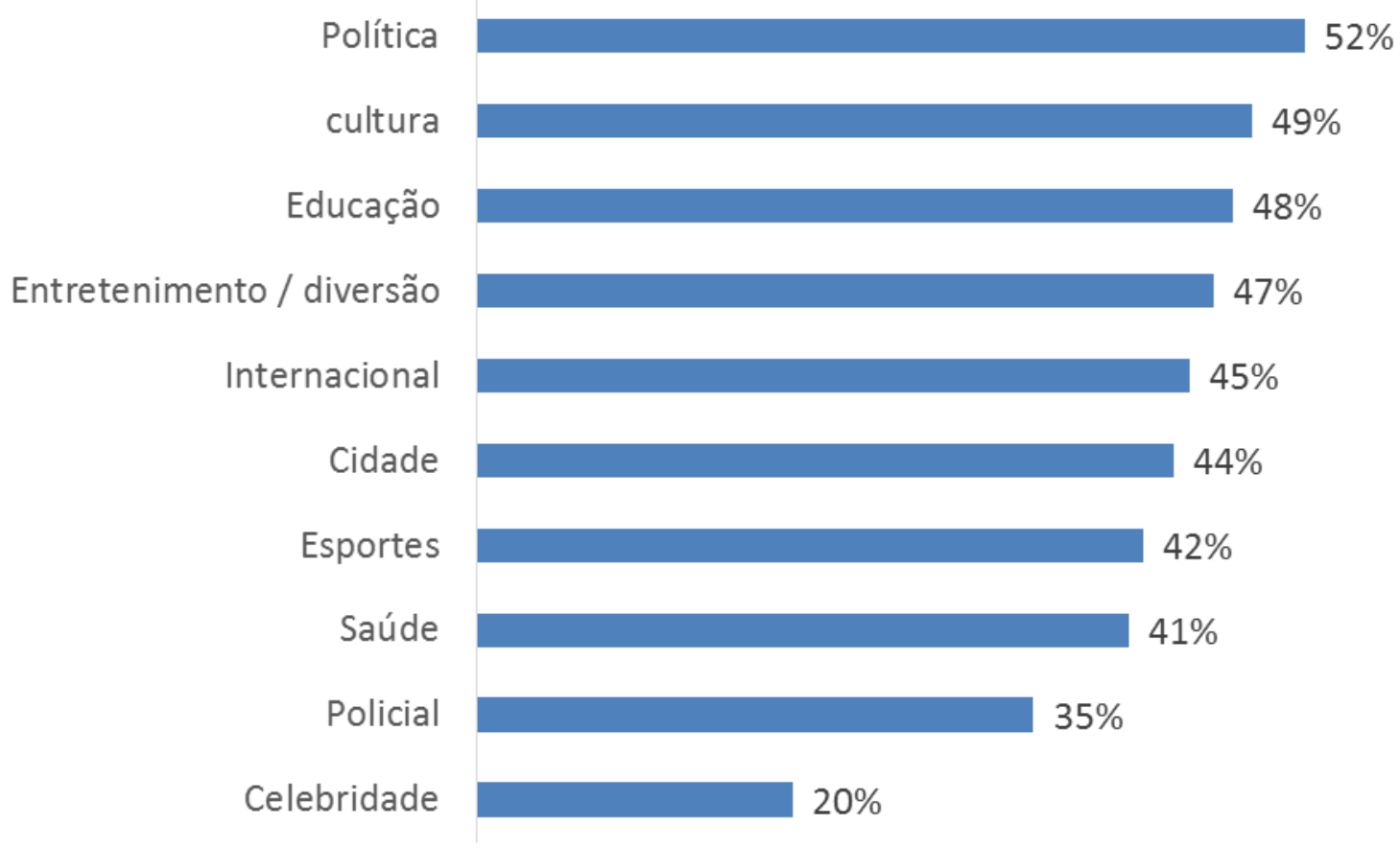

Fonte: da autora

Mais da metade dos estudantes (52\%), utilizando o cálculo ponderado entre todas as respostas, optou pelo tema política em primeiro lugar. Com $49 \%$ ficou a editoria de cultura e a de entretenimento/diversão apareceu em quarto lugar (47\%), abaixo de educação (48\%). O interesse por assuntos internacionais e da cidade aparecem praticamente equivalentes (45 e $44 \%$ ), indicando que os universitários curitibanos são igualmente motivados a se informar a respeito de temas próximos e de temas distantes. A busca por informações de esporte foi identificada por $42 \%$ do universo pesquisado, enquanto as 'fofocas' a respeito da vida de celebridades atraem $20 \%$ dos respondentes, em último lugar na escala; e a editoria policial, marcada no geral pelo jornalismo sensacionalista, ficou em penúltimo lugar, com $35 \%$.

Estes números foram encarados com ironia e descrença pelos acadêmicos de Jornalismo. A maioria considerou inverídicas as respostas, em especial a comparação entre os interesses declarados por assuntos políticos e o noticiário envolvendo celebridades. No debate desenvolvido em sala de aula considerou-se, ademais, que a utilização das editorias clássicas do jornalismo (educação, saúde, cidade, policial, internacional etc) deixou de lado assuntos potencialmente de interesse do público pesquisado, como a tecnologia, por exemplo. 
Os dados totalizados na pesquisa junto aos estudantes curitibanos diferem da sondagem promovida junto a alunos de Comunicação Social da UFMG:

Uma pergunta estruturada em forma de escala de ordenamento de importância foi apresentada aos respondentes para saber que tipo de notícias eles procuravam na Internet. As notícias sobre Arte e Cultura atingiram as mais altas taxas de preferência dos universitários quando comparadas com o grau de importância em relação a outras notícias. Para 44,9\% dos respondentes, as notícias na Internet sobre Arte e Cultura têm alta importância. Essa taxa sobe para $72 \%$ da preferência, se consideradas as respostas "Alta Importância" e "Relativa Importância". O quesito "Nenhuma Importância" para esse assunto não foi marcado por nenhum dos respondentes. Em contrapartida, as notícias sobre tecnologia apresentaram o maior grau de rejeição entre as categorias. Para apenas três universitários $(4,3 \%)$, tecnologia foi considerada um assunto de alta importância. (...) Já as notícias sobre esportes polarizaram os universitários, revelando que para 23,2\% elas são de alta importância, 18,8\% de relativa importância, $20,3 \%$ de baixa importância e $24,6 \%$ de nenhuma importância (JOHNSON, 2007, p. 9).

Uma das explicações possíveis para os dados coletados em Curitiba é o fato de o maior contingente da amostra ser composto por estudantes do curso de Direito que, pelo menos teoricamente, têm maior interesse pelos temas políticos. De qualquer maneira, o resultado não deixa de ser surpreendente, assim como a preferência indicada em quinto lugar pelo noticiário internacional, em geral uma temática considerada distante dos interesses juvenis.

\section{Cruzamentos entre os questionários}

$\mathrm{Na}$ elaboração dos instrumentos de coleta de dados da presente pesquisa uma das preocupações foi estabelecer um mecanismo de aferição das respostas dadas no primeiro questionário, no qual os universitários indicaram quais são seus hábitos de consumo de informação de atualidade. Como já foi mencionado, o principal receio seria que, por estarem respondendo a estudantes de Jornalismo, houvesse uma tendência de amplificar o nível real de interesse e/ou consumo de notícias. É necessário considerar também a existência de uma expectativa social de que as pessoas deveriam ser bem informadas, ainda mais as que têm curso superior. Em função disso foi elaborado o segundo questionário, distribuído depois que os estudantes informavam que haviam completado o primeiro formulário. Nele, seis questões de múltipla escolha tratavam de notícias veiculadas nas 72 horas precedentes à aplicação do instrumento e versando sobre diversos temas, desde política internacional e nacional, passando por assuntos locais, esporte, cultura e outros. 
Havia ainda uma última questão, composta por dez itens, na qual o entrevistado era solicitado a relacionar as colunas da esquerda e da direita. À esquerda estavam nomes de pessoas, instituições ou lugares e à direita algum complemento, igualmente baseado em informações noticiosas veiculadas nos dias precedentes à aplicação. O nível de acerto total desta questão foi bastante elevado (68\% dos entrevistados que responderam fizeram as dez associações corretamente e menos de 0,5\% acertaram até cinco associações), restando uma indagação a respeito da eficácia da formulação, isto é, se as associações tinham caráter eventualmente muito óbvio, pela forma em que foram redigidas. Muitos respondentes que haviam errado a maior parte das questões anteriores acertaram majoritariamente esta última. Para evitar alguma distorção dos resultados, optou-se por não levar em consideração, nos cruzamentos efetuados entre os dois questionários, a sétima questão.

Quando é efetuado o cruzamento da primeira questão do questionário um - que indagava a periodicidade com que o estudante busca informação jornalística por qualquer meio -, com o nível de acerto das questões de múltipla escolha do questionário dois, tem-se a confirmação de que as pessoas que mais procuram ter conhecimento das notícias, melhor estão informadas sobre temas da atualidade. Para facilitar a leitura e o entendimento dos dados, a opção foi enquadrar os níveis de acerto em três escalas, conforme a Tabela I, abaixo. Neste quadro foram desconsiderados os únicos três respondentes, do total de 470, que acertaram as seis questões do questionário de aferição.

Tabela I - Frequência de busca por notícia $X$ acertos no questionário 2

\begin{tabular}{|l|l|l|l|}
\hline $\begin{array}{c}\text { Periodicidade de busca por } \\
\text { informação }\end{array}$ & $\begin{array}{l}\text { Até um } \\
\text { acerto }\end{array}$ & $\begin{array}{l}\text { De a 3 } \\
\text { acertos }\end{array}$ & $\begin{array}{l}\text { Entre 4 e } \\
\mathbf{5} \text { acertos }\end{array}$ \\
\hline Todos os dias & $17,0 \%$ & $59,6 \%$ & $23,0 \%$ \\
\hline $\begin{array}{l}\text { Algumas vezes por semana } \\
\text { colegas sobre um assunto }\end{array}$ & $27,4 \%$ & $59,4 \%$ & $13,1 \%$ \\
\hline Raramente busco informação & $26,3 \%$ & $47,3 \%$ & $26,3 \% *$ \\
\hline Não busco informação & $47,3 \%$ & $36,8 \%$ & $15,7 \% *$ \\
\hline
\end{tabular}

*Entre os estudantes que declararam raramente buscar informações ou que nunca buscam, houve registros máximos de 4 acertos - nenhum acertou a 5 respostas. 
Fonte: da autora

Os dados apontam que, embora exista uma concentração significativa de respondentes que acertaram em torno da metade das questões, localizando-se entre 2 a 3 respostas corretas, há diferenças nítidas nas extremidades da tabela. Assim, quem busca informação todos os dias apresentou um percentual menor de um único acerto (17\%) e um percentual maior respostas corretas entre 4 a 5 questões (23\%). Já entre os universitários que não buscam informação, quase a metade $(47,3 \%)$ acertaram apenas uma questão e nenhum acertou 5 respostas $(15,7 \%$ deles responderam positivamente a 4 questões).

A Tabela II, a seguir, promove o cruzamento dos veículos mais usados pelos estudantes na busca da notícia com as quantidades de acertos nas questões objetivas do questionário dois.

Tabela II - Veículo mais usado na busca por notícia $\mathrm{X}$ acertos no questionário 2

\begin{tabular}{|l|l|l|l|}
\hline $\begin{array}{l}\text { Veículo utilizado para a } \\
\text { busca de informação }\end{array}$ & $\begin{array}{l}\text { Até } \\
\text { acerto }\end{array}$ & $\begin{array}{l}\text { De a } \mathbf{3} \text { acertos } \\
\mathbf{5} \text { acertos }\end{array}$ \\
\hline Lê jornal todos os dias & $19,8 \%$ & $55,5 \%$ & $24,6 \%$ \\
\hline Lê jornal 2 vezes por semana & $24,5 \%$ & $58,1 \%$ & $17,2 \%$ \\
\hline Nunca lê jornal & $40,3 \%$ & $45,1 \%$ & $14,5 \%$ \\
\hline $\begin{array}{l}\text { Acessa sites de notícia várias } \\
\text { vezes por dia }\end{array}$ & $16,2 \%$ & $59,4 \%$ & $24,3 \%$ \\
\hline Acessa sites diariamente & $18,1 \%$ & $58,7 \%$ & $23,0 \%$ \\
\hline Nunca acessa sites de notícia & $40,0 \%$ & $50,0 \%$ & $10,0 \% * *$ \\
\hline Assiste noticiários na televisão & $23,5 \%$ & $58,5 \%$ & $17,6 \%$ \\
\hline Raramente assiste TV & $28,1 \%$ & $56,2 \%$ & $15,4 \% * *$ \\
\hline Acompanha notícias no rádio & $23,2 \%$ & $57,9 \%$ & $18,8 \%$ \\
\hline Raramente ouve rádio & $28,7 \%$ & $58,5 \%$ & $12,7 \%$ \\
\hline
\end{tabular}

**Quem nunca acessa sites de notícias ou raramente vê televisão obteve, no máximo, 4 acertos. 
Fonte: da autora

O hábito de leitura diária de jornal e o acesso a sites de notícias (diariamente, ou mesmo várias vezes por dia) faz a diferença no nível de conhecimento de informações de atualidade. Os universitários que apontaram estas práticas, efetivamente acertaram maior número de questões do questionário de aferição: $24 \%$ alcançaram entre 4 e 5 acertos e menos de $20 \%$ obtiveram apenas um acerto. Entre os que acompanham noticiários pela televisão ou pelo rádio os resultados foram inferiores: o número de acertos de até uma questão foi equivalente (23\%), a média de 2 e 3 acertos ficou em $58 \%$ e em torno de $18 \%$ o índice de 4 e 5 acertos.

A leitura é apontada por Pina (2011, p.3) como "instrumento de formação de sujeitos críticos, capazes de refletir, sob óticas variadas, acerca do mundo em que vivem e que constroem em seu cotidiano interpretando-o". A autora cita Eliana Yunes:

Ler é inscrever-se no mundo como signo, entrar na cadeia significante, elaborar continuamente interpretações que dão sentido ao mundo, registrá-las com palavras, gestos, traços. Ler é significar e, ao mesmo tempo, tornar-se significante. A leitura é uma escrita de si mesmo, na relação interativa que dá sentido ao mundo (Yunes, 2009, p.53, apud PINA, 2011, p.3).

$\mathrm{O}$ ato da leitura - seja de textos literários, acadêmicos ou noticiosos, como no caso do foco da presente pesquisa - coloca o leitor no mundo, em um processo simultâneo e recíproco de reconstrução e transformação. Ao mesmo tempo, a leitura não pode ser considerada uma atividade neutra, pois ela se insere em um campo de disputa, no qual estão imersas as relações sociais, e significa uma busca de poder por meio do conhecimento.

\section{Considerações finais}

De acordo com Bezerra e Torres ( 2011, p. 3), “(...) o hábito e o consumo relacionamse por serem ações moldáveis a qualquer atividade humana inseridas no cotidiano da sociedade. Em relação ao consumo, em destaque o da informação, seja em qualquer tipo de mídia acontece pelo livre interesse do cidadão, onde o mesmo tem a capacidade de selecionar o melhor segmento noticioso que lhe é oferecido". Na dinâmica do dia-a-dia, sobretudo de jovens universitários que, presume-se, têm um ritmo acelerado de atividades, o hábito de consumir informações jornalísticas, que a presente pesquisa procurou dimensionar, efetivamente se estabelece por uma decisão individual, em especial porque os cursos pesquisados não têm, via de regra, programas de incentivo à leitura de notícias. Esta prática 
pode estar relacionada a alguma herança familiar - o exemplo dos pais quase sempre se reproduz no comportamento dos filhos - ou mesmo a alguma propensão majoritária entre os respondentes da pesquisa.

O fato de $74 \%$ dos estudantes de Engenharia Civil e Direito, de quatro diferentes instituições de ensino em Curitiba, responderem que buscam informações noticiosas diariamente ou "algumas vezes por semana" é um dado alentador e configura um panorama otimista para os jornalistas e as empresas jornalísticas no futuro. A existência de tecnologias que facilitam o acesso a informações, indicam várias das pesquisas citadas ao longo deste texto, parecem impulsionar o consumo de notícias, sobretudo por meio dos dispositivos móveis que tornam mais populares e acessíveis a cada dia:

\begin{abstract}
Com o advento das novas tecnologias digitais, a juventude brasileira, ou a geração do século 21 , nascida a partir de 1990 , passou a ter acesso a uma nova forma de interpretar a realidade, como também mudou a forma de consumir a mídia. As Tecnologias de Informação e Comunicação além de seduzirem os jovens, transformaram-se em um verdadeiro laboratório de criação para os jovens que já nasceram plugados e estão a desafiar os modelos tradicionais (MATTOS, 2010, p.147).
\end{abstract}

Nos meios jornalísticos são intensos os debates em torno da qualidade das informações disponibilizadas on line e do fato de configurarem, realmente, produtos noticiosos elaborados com base nos cânones forjados ao longo dos vários séculos de atuação da imprensa. Evidentemente, um expressivo volume destas postagens está longe de buscar a apuração da notícia com isenção e pluralidade; de buscar atender às determinações éticas do jornalismo; não tem o compromisso claro com a verdade factual; desconsidera o interesse coletivo como preponderante; não se preocupa em atuar como um monitor independente dos poderes (político, econômico etc). Todos estes são aspectos essenciais ao jornalismo e aos jornalistas que, desde sua formação acadêmica, são instados a refletir a respeito deles - e a desenvolver suas práticas com base nestes preceitos.

Há teóricos, como Pierre Lévy (1999) por exemplo, que acreditam na possibilidade de utilização destas novas tecnologias para construção de uma sociedade de plena realização, democrática e participativa. Outros, como Bechelloni (2010, p. 408) demonstram uma postura mais preocupada:

Há quem exalta o "novo que avança", como uma grande e positiva revolução democrática. E aqueles que temem que devido às mudanças que as novas tecnologias e a prática social por elas induzida - como Facebook (300 milhões de utentes no mundo), os celulares ( 4 bilhões e meio, no mundo), Twitter e quantos mais - esteja se abrindo uma nova idade bárbara (a partir do desaparecimento do direito do autor, do 
livro e das bibliotecas, da democracia representativa e, sobretudo, da pessoa humanacomo aponta Halprin).

Estamos de fato, enquanto espécie dominante no planeta, enfrentando grandes transformações e desafios (o principal deles é nossa própria manutenção, condicionada pelo equilíbrio ecológico). No que tange à comunicação e ao jornalismo, as perspectivas parecem amplas e não necessariamente pessimistas. $\mathrm{O}$ interesse manifestado pelos universitários curitibanos participantes desta pesquisa, evidenciado não apenas no alto percentual dos que cultivam o hábito de consumir notícias como também nas temáticas preferenciais apontadas por eles, parece indicar que a recepção efetivamente mudou, conforme argumentam Souza e Castro, em decorrência da internet. E isso está impulsionando novos horizontes da própria pesquisa na área: "Os dados apontam uma nova tendência nas pesquisas sobre jornalismo. Se antes os estudos de recepção ficavam relegados, o público era pouco conhecido ou estudado, hoje em dia o cenário caminha em uma nova direção. Seja com uma visão crítica ou entusiástica, os pesquisadores convergem em um ponto: a recepção mudou" (SOUZA e CASTRO, 2012, p. 7). O levantamento que agora se encerra - e que pretende desenvolver uma segunda etapa de caráter qualitativo - espera contribuir neste trajeto.

\section{Referências}

BECHELLONI, Giovanni. Revolução digital ou barbárie digital? O conhecimento das coisas do mundo para combater os inimigos da boa comunicação na sociedade globalizada. In: BARBOSA, Marialva e MORAIS, Osvaldo (orgs). Comunicação, cultura e juventude. São Paulo: Intercom, 2010

BEZERRA, Maria dos Remédios de Sousa e TORRES, Jaqueline da Silva. Os jovens e a informação jornalística do rádio . Disponível em: http://intercom.org.br/papers/regionais/nordeste2011/resumos/R28-1074-1.pdf. Acesso em $20 / 12 / 2013$

BOURDIEU, Pierre. A Miséria do Mundo. Petrópolis/RJ: Vozes, 2007 pp. 693-713

BRASIL. O Estado de uma Nação, 2006. Disponível em http://www.ipea.gov.br/portal/index.php?option=com_content\&view=article \&id=5535. Acesso em 20/12/2013

CATANI, FRÂNIO Mende e GILIOLI, Renato de Souza. Culturas Juvenis, múltiplos olhares. São Paulo: Ed. Unesp, 2008

CHAVES, Marcelo Mesquita. A geração Y e o consumo de informação jornalística esportiva: motivações de consumo, meios e veículos de comunicação. Monografia de graduação. Universidade Federal do Rio Grande do Sul. Escola de Administração. Curso de 
Administração, Porto Alegre, 2012. Disponível em

http://www.lume.ufrgs.br/handle/10183/72999. Acesso em 28/12/2013

DOSSIÊ Universo Jovem 5 MTV. Disponível em:

http://www.aartedamarca.com.br/pdf/Dossie5_Mtv.pdf - acesso em 8/2/2014

DUARTE, Jorge. Entrevista em profundidade. Disponível em

http://pt.scribd.com/doc/38899413/Entrevista-Em-Profundidade. Acesso em 13/02/2014

FARIAS, Tarcia P. e MEDITSCH, Eduardo. A percepção dos jovens de Florianópolis sobre o jornalismo. Disponível em

http://www.intercom.org.br/papers/regionais/sul2008/resumos/R10-0179-1.pdf. Acesso $18 / 12 / 2013$

HALLIDAY Josh. A Leitura de jornais em tablets aumenta entre jovens britânicos. In: Observatório da Imprensa, jan. 2013. Disponível em: http://www.observatoriodaimprensa.com.br/news/view/_ed730_leitura_de_jornais_em_tablet s_aumenta_entre_jovens_britanicos. Acesso em 13/03/2013

JOHNSON Telma Sueli Pinto. Entre novas e velhas mídias: práticas de busca de informação da vida cotidiana entre jovens. 2007. Disponível em: http://www.bocc.ubi.pt/pag/johnsontelma-entre-novas-e-velhas-midias.pdf Acesso em 30/11/2013

KARAN, Francisco J. C. Jornalismo, Juventude e Sociedade de informação e de conhecimento. In: BARBOSA, Marialva e MORAIS, Osvaldo (orgs). Comunicação, cultura e juventude. São Paulo: Intercom, 2010

KOVACH, Bill e ROSENSTIEL, Tom. Os elementos do jornalismo. São Paulo: Geração Editorial, 2004

LÉVY, Pierre. A inteligência coletiva. Por uma antropologia do ciberespaço. São Paulo: Loyola, 1999

MAMEDE-Neves, Maria Aparecida e PEDROZA, Stella Maria P. A. Quem lê tanto notícia? O jovem universitário e o jornal impresso. In Revista Famecos, n. 40. Dezembro de 2009. Disponível em http://132.248.9.34/hevila/RevistaFAMECOS/2009/no40/11.pdf. Acesso em $16 / 12 / 2013$

MATTOS, Sérgio. O imaginário da juventude, a televisão e as tecnologias digitais. In: BARBOSA, Marialva; MORAIS, Osvando (orgs.). Comunicação, cultura e juventude. São Paulo: Intercom, 2010

McCOMBS, M. e SHAW, D. A função do agendamento dos media. In: TRAQUINA, N.(org.) O poder do jornalismo. Coimbra: Minerva, 2000, p.47-61.

MEC, Portal. Censo aponta aumento de 4,4\% e matrículas superam 7 milhões. Disponível em: http://portal.mec.gov.br/index.php?option $=$ com_content\&view=article\&id=19077:censoaponta-aumento-de-44-e-matriculas-superam-7-milhoes-\&catid=212. Acesso 18/12/2013

OBSERVATÓRIO da Imprensa. Leitores de jornais não estão envelhecendo. Disponível em: 
http://www.observatoriodaimprensa.com.br/news/view/_ed730_leitores_de_jornais_estao_en velhecendo Acesso em 13/03/2013

REZENDE, Guilherme Jorge. Telejornalismo no Brasil: um perfil editorial. São Paulo: Summus, 2000.

SCHLAUCHER, Bárbara Garrido de Paiva. Telejornalismo e juventude na era da convergência midiática In: INTERCOM SUDESTE, 2012, Ouro Preto, MG. Anais... Ouro Preto: Universidade Federal de Ouro Preto, 2012. 1 CD-ROM.

SOUSA, Jorge Pedro. Teorias da notícia e do jornalismo. Chapecó: Argus, 2002.

SOUZA, Jana e CASTRO, Davi. Os caminhos da recepção: uma análise da produção científica brasileira. In: Anais da VIII Conferência Brasileira de Mídia Cidadã. Disponível em: http://www.unicentro.br/redemc/2012/artigos/45.pdf. Acesso em 25/02/2013

Original submetido em : 28/02/2014

Aprovado para publicação em 22/11/2014

\section{Sobre a autora}

Elza Aparecida Oliveira Filha

Doutora em Ciência da Comunicação pela Unisinos (2006), mestre em

Sociologia pela UFPR (2002), jornalista profssional com mais de 20 anos de atividade na imprensa diária. Ex-coordenadora da DT

Jornalismo Impresso da Intercom. Professora Universidade Tecnológica Federal do Paraná. 